\title{
Dubowitz Syndrome
}

National Cancer Institute

\section{Source}

National Cancer Institute. Dubowitz Syndrome. NCI Thesaurus. Code C125591.

A rare, autosomal recessive inherited syndrome characterized by microcephaly, growth retardation, and a small, round, triangular shaped face with a pointed, receding chin, a broad, wide-tipped nose, and wide-set eyes with drooping eyelids. 